\title{
Guru Bacarita: An Encounter With Post-Conflict Peacebuilding in Ambon
}

\author{
Abdul Jamil Wahab \\ \{ajamilwahab@gmail.com\} \\ The Research and Development Center for Religions and Religious Services, Ministry of Religious \\ Affairs.
}

\begin{abstract}
The Ambon conflict was a deadly clash and devastating violence between two religious communities, Muslims and Christians. The conflict has resulted in enormous losses and casualties on both sides. Many efforts for reconciliation and peace building have been made, both by the government and communities. All efforts or approaches have weaknesses, but they serve to complete one another. One of the peace-building efforts initiated by the communities is the "Guru Bacarita" (Teachers Meet) program. This program involves teachers from several schools. They were probably teenagers or kids when the conflict occurred in 1999 to 2004. With a qualitative approach, this study finds out that the conflict has left a psychological impact, known as Post-Traumatic Stress Disorder (PTSD). Here, "Guru Bacarita" has become an "antidote" and a meeting room (bakudapa) for teachers from different religious backgrounds. In addition, it has also succeeded in building intimacy which has eventually created an awareness of mutual need, instead of mutual blame between different communities. In this program, the teachers are invited to visit houses of worship and learn about religious diversity in order to foster tolerance and inclusion. In short, the program plays a significant role in building stronger relationships among groups of people from different religions.
\end{abstract}

Keywords: Guru Bacarita, Bakudapa, Peace Building, Post-Traumatic Stress Disorder.

\section{Introduction}

Indonesia has encountered several communal conflicts concerning religious backgrounds, one of which is the Ambon conflict involving Muslims and Christians. The conflict that lasted from 1999 to 2004 did not only happen in Ambon, but also in other areas in Maluku Province, Halmahera and Ternate, among others. It was considered a deadly conflict which involved most of religious communities from both sides and consequently resulted in thousands of people dying, injured and displaced.

The conflict which later became a bloody tragedy in Ambon and Maluku was initially triggered by a fight between an angkot (public transport) driver and one of his passengers; a young Christian named Jacob Leuhery from Mardika and a young Bugis Muslim named Mursalim a.k.a Salim from Batu Merah. Unfortunately, the fight turned into a communal conflict within hours. The conflict, which began on January 19, 1999, coincided with the 1419 Eid Al-Fitr celebration. Like pouring gasoline on the fire, it frightfully burned out and was unable to stop. Even though several peace efforts were made, the dynamics of the conflict kept going until five or six years. According to an interview with some of the residents, it was not until 2005 that tensions had eventually started to subside.

The fight, which was started by the two young men, then developed into an ethnic fight. Initially, the emerging issue was the expulsion of migrants mainly from Buton, Bugis and Makassar (BBM) by Ambonese local residents. Warnings in terms of banners, posters, or 
murals saying "Usir BBM/Get Rid of BBM" took place in several locations. Shockingly, such ethnic issue then turned into conflict that brought out religious identity. A rumor about the burning of the Silo church by Muslim community and the burning of the Al-Falah mosque by Christian community came up. This rumor provoked those who have religious fanaticism to get easily disturbed and immediately show negative reactions.

The communal conflict in Maluku and North Maluku has claimed 8000-9000 lives and caused 700 thousand residents to displace. In addition, it has also caused material losses; 29 thousand houses burned down and 7.046 houses, 45 mosques, 57 churches, 719 shops, 38 government buildings, and 4 banks damaged (LSI Survey, 2012). This conflict is one of the biggest religious conflicts in Indonesia and even in the world in the 21 st century. It did not only take a lot of lives and property, but also caused very complex social damages.

The conflict, which initially occurred in Ambon, extended to other Maluku regions. Riots then occurred in several islands such as Kairatu Island (Seram) on February 3-5, 1999, Haruku Island on February 13-14, 1999, Saparua Island on February 23, 1999, Kei Besar Island on April 3, 1999, Kei Kecil Island in mid April 1999, and West Seram on August 18, 1999 respectively. The riots even spread to Halmahera Island around mid-August, Tidore Island on November 5, 1999, and eventually broke out in Ternate.

The conflict subsided when the Malino II Accord was signed on February 12, 2002. However, the signing of the Accord was not the end of the conflict. A day later, another conflict came up; a bomb exploded in Mahardika and Batu Merah. The socialization of the Accord was even marred by riots and the Maluku Governor's Office was burned down. However, several important things were taken into account after the Accord was declared, no more village attacks by different religious groups and the dissolution of Laskar Jihad by its leader, Ja'far Umar Thalib. It was then followed by its withdrawal from Maluku to Java (Sumanto Al- Qurtuby.2018: 73-74).

The issues on conflict and peace in Maluku have attracted the attention of many social scientists. Many have written about the processes and stages of the conflict and the reasons why it happened in the beginning. Some of them have also produced the conflict resolution strategies that have been taken. Both the government and the society have even admittedly made many reconciliation efforts. However, to deal with a large-scale conflict, like the one in Maluku, a large, holistic and comprehensive effort which is sustainable and involves all components in society is required.

Peace is everyone's dream, but sadly not everyone strives to build peace as it requires them to work together and help one another. Without working together, it is really hard to achieve. For this reason, all peace-building efforts that have been carried out need some appreciation and must be sustained. All approaches have weaknesses, but they serve to complete one another.

As part of the efforts to explore best practices of peace building, the writer is interested in studying the effort made by the people in Ambon through the Guru Bacarita program. This program which is attended by interfaith teachers was initiated in 2018.

To that end, several research questions are proposed; What are the Guru Bacarita program designs?; Is it effective to build stronger relationships between groups of people with different religions? If so, what values are considered supporting in maintaining and building peace in Ambon?

This study uses a qualitative approach and the data are collected through interview, observation, and documentation. The interview, for instance, was conducted in July 2020 and addressed to religious leaders from Indonesian Ulema Council and Maluku Protestant Church in Maluku, the Ministry of Religious Affairs officials in Ambon, several Ambonese peace 
figures including Baihajar Tualeka, the founder of the LAPPAN organization, the teachers participating in the Guru Bacarita program, and communities that have been involved in the conflict.

\section{Literature Review}

\subsection{Theoretical Framework}

The word Post-conflict Peace Building in common sense is an agenda to respond to an ongoing violent conflict. It aims at promoting peace and eradicating violent conflict, enmity, social disharmony, and alike. Basically, the efforts on the post-conflict peace building are not only carried out until the conflict subsides considering that its objectives are not merely ending conflicts and maintaining peace agreements. However, its concept includes broad and comprehensive works both in conflict and post conflict situations.

Peace building is mostly directed as an active effort to rebuild society so that the existing peace can continue and seek reconciliation in conflicted areas. In addition, it can also play a role as a reintegration to a more peaceful situation which encourages an effective and fair court process, promotes the participation in politics proportionally, and respect culture, customs and religions. With these roles and functions, it eventually becomes a common agenda. Plans, expectations, and implementations are continuously pursued (Ala'i Nadjib. 2007: 10).

John Galtung, a peace study researcher from Norway, mentions peace-building is a process aimed at the practical implementation of peaceful social change through political, social and economic reconstruction and development. In the conflict mapping, he introduces the concept of the conflict triangle or $\mathrm{ABC}$ triangle; attitude, behavior and contradiction, the difference among direct, structural and cultural violence, and the difference between negative and positive peace (Johan Galtung, Dietrich Fischer. 2013: 172-178).

Galtung also introduces conflict resolution consisting of peace-making, peace-keeping, and peace-building. The peacekeeping, for example, involves security forces or the military to deal with a conflict. Such action is taken to end unstoppable conflict. In the meantime, the peace-making is an effort made by policy makers to negotiate with parties to find a way out of conflict (Michelle I. Gawer. 2016: 439). This is an attempt to negotiate with groups who have different views and interests. Further, the peace-building is a strategy and effort that attempts to restore the destructive situation due to a conflict by building and bridging communication between parties more broadly, involving all parties and departing from the grassroots level, to develop a structured peace based on justice and equality of all parties.

According to Galtung, peace-building places greater emphasis on long-term process, traces and resolves the roots of conflicts, changes contradictory assumptions, and strengthens elements that can connect conflicting parties in a new formation in order to achieve positive peace.

His explanation is supported by Andy Knight, a Canadian political scientist, in his book Building Sustainable Peace. He states peace-building has something to do with two essential things, deconstructing violence structure and reconstructing peace structure. Further, he adds the main objectives of peace-building are to prevent or resolve conflicts and create a peaceful situation by transforming a culture of violence into a culture of peace.

To initiate peace, it requires commitment from all parties to take part in realizing it. On the one hand, community members should initiate the peace process with all resources they have. On the other hand, the government with its authority supports the efforts made by the pro-peace community in order to bring peace to reality. 


\subsection{Previous Studies}

This study is not the first one to explore peace-building in Maluku. There have been several previous studies finding out about forms of peace in Maluku. The study entitled Pasar; Bakudapa Bangun Rekonsiliasi, Refleksi peran perempuan Papalele dalam Resolusi Konflik and conducted by Rizard Jemmy Talakua, for instance, reveals the activities of papalele or female traders in Ambon. Without them knowing, they have helped the conflict resolution process. Their role in the peacekeeping, peacemaking, and peace-building stages makes them anomalous in conflict resolution and diplomacy studies.

Second, a study entitled Kerjasama antarumat Beragama: Studi Rekonsiliasi Konflik Agama di Maluku dan Tual by Yunus Rahawarin draws some conclusion that the conflict in Maluku and Tual has very complex dimensions of conflict. To that end, the conflict resolution efforts are not only limited to making efforts to end violence and disputes, but also requiring social reconstruction and strengthening the local identities in the two regions.

Third, a study entitled Sape Bale Batu, Batu Bale Dia: Politik Revivalisme Tradisi Siwa Lima Orang Ambon Pascakonflik by Hatib Abdul Kadir has discovered that long before the Moluccans knew Indonesia, they have been familiar with the term siwa lima (shiva's five), a belief claiming that they came from one ancestor, even though their descendants are later divided, some are Christians and the others are Muslims. This local wisdom is considered as a basic philosophical view in building social harmony. Almost all Ambonese people have regretted the riots that occurred, and they now feel that they have betrayed their ancestor who took the trouble to create the shiva lima and pela-gandong. In addition, an expression bale batu, batu bale dia is commonly known among them. The expression means whoever turns over a stone; the stone will turn them over. Whoever forgets customs and traditions, the customs and traditions will turn them around.

These studies have something in common with the writer's study, examining peacebuilding practices carried out by the communities in Ambon or Maluku in general. They see the importance of revitalizing local wisdom, in terms of the role of papalele women, the siwa lima tradition, social reconstruction and strengthening local identity. It has great potential to create long-term peace building. What makes this study distinctive and different from the others is that it describes and analyzes the Guru Bacarita program which is attended by teachers from different schools in Ambon.

\subsection{Bakudapa; Peace Building Efforts in Ambon}

The government and institutions and parties at the national and local scale from the two communities (Islam and Christianity) have different approaches to reveal the root cause of the conflict between the two from various perspectives. Even claiming to be neutral, it turns out the humanitarian conflict in Ambon has not subsided and has consumed a very long period of time, about four years (1999-2003), compared to other conflicts taking place in other areas. It has also resulted in countless victims in terms of lives and properties (Jan S. Aritonang. 2004: 544).

The issue about socio-religious conflict in Ambon is not likely to approach only with "one" dimension of life. However, it does not mean that it is wrong and impossible at all. Some reconciliation will only become a discourse if no one starts it and is committed to presenting a perfect or flawless solution. It is precisely when everyone realizes that all approaches have dimensions of weakness and functions to complement one another, and when all aspects of life are explored and used as points of view in framing reconciliation discourse and actions. 
Shortly after the conflict, a number of efforts were made by the government in building peace in Ambon and areas experiencing other social conflicts. Since the conflict broke out, the government had made efforts to resolve it by connecting and rebuilding the social relationship among the Maluku boys, which stopped due to the conflict. Other efforts made by the Maluku Provincial Government include: (1) organizing a parade with regional officials and important interfaith figures which is intended to call the people to immediately stop the violence, (2) reading out the "Declaration of Refraining-Ending Conflict" signed by the representatives of religious leaders and local government, (3) mobilizing the participation of local elites at the village level by supporting the latupatti (kings of the country in Maluku) to take part in conflict reconciliation. In the meantime, the central government has adopted three approaches: (1) security approach, (2) rehabilitation approach, and (3) reconciliation and peace approach. Finally, the pinnacle of peace was gained with the implementation of "Maluku Meeting in Malino" on February 11-12, 2002 which resulted in 11 accords, the "Maluku Accords in Malino".

The religious leaders played a very significant role in creating peace. Several figures including Husein Toisuta, Imam Masjid al-Huda Ahuru, Father John Sahalessy from Wayame, Father I.J.W. Hendriks, the Chairperson of the 2000-2005 Maluku Protestant Church Synod, and female leaders of the Women's Care Movement (Gerakan Perempuan Peduli/GPP) have agreed to call on the government and all parties to end the conflict through various efforts.

Even though the conflict has passed for more than 21 years, efforts to build and maintain peace have been made until now. The Maluku Protestant Church, Indonesian Ulema Council, the Ministry of Religious Affairs in Ambon, and Lingkar Pemberdayaan Perempuan dan Anak/LAPPAN (Circle of Women Empowerment And Child Protection) as the nongovernmental organization have kept taking part in building peace. Some of their best practices include building relationships between Indonesian National Armed Forces and Indonesian National Police, gathering religious leaders through interfaith forum, campaigning for "Orang Basudara" slogan, conducting A Walk Together for interfaith harmony, providing humanitarian social assistance, teaching Christian ethics education (Pendidikan Etika Kristen/Petik ) and inclusive religious values, creating cultural revitalization that supports multiculturalism such as Pela Gandong and Safari Dakwah Kebangsaan programs, conducting a meeting for leaders/administrators of houses of worship, providing rehabilitation assistance for houses of worship, creating dialogues for interfaith teachers and students, conducting a teacher and student visit to schools of different religions, creating interfaith dialogue and meeting for religious leaders, conducting a visit to houses of worship (from groups of different religions) individually or in group, and organizing Guru Bacarita program.

In this study, the writer focuses on a peace effort made by the LAPPAN/ Lingkar Pemberdayaan Perempuan dan Anak (Circle of Women and Children Empowerment) organization. It is a local Ambonese organization founded by Baihajar Tualeka ${ }^{1}$ after the Malino II Accord was signed in February 2002. Baihajar Tualeka accordingly initiated to establish the organization as a forum to empower women and children and have discussions among interfaith communities. The establishment of this organization is a concrete manifestation of determination to build and maintain peace in Maluku.

In order to maintain peace in Maluku, several programs are created by LAPPAN, one of which is Guru Bacarita. This program is funded by YCG (Yayasan Cahaya Guru) in

${ }^{1}$ Baihajar won the Saparinah Sadli Award in 2012, as an inspiring woman for her thoughts and actions in creating peace in Maluku. A year later, she was given the 2013 Indonesian Women of Change Award from the government of the United States (US). 
Jakarta. It was created in 2018, aiming to recruit about 50 interfaith teachers from each school. In practice, it has been conducted in several schools, SMPN 9 Ambon, SMPN 4 Salahutu, and MTs al-Ikhlas Ambon, among others. There are two major agendas in this program; Focus Group Discussion and visits to houses of worship (An interview with Baihajar Tualeka on July 18, 2020 in Ambon).

The Focus Group Discussion (FGD) uses bacarita approach to provide wider space for teachers to become a source of learning for one another. This discussion has become their meeting place although they come from different religious backgrounds to share their experiences in surviving the social conflict in 1999-2004 in Maluku, their troubles or suffering due to the loss of their houses, properties, family members, and others. They also share their longing for togetherness that was once created but suddenly vanished due to this turmoil of human tragedy.

As Guru Bacarita means Teachers Tell, the teachers are welcome to share their experiences in facing the conflict in the past. Each is given an opportunity to tell what they saw, heard, thought, and felt during the conflict. They were probably teenagers or kids when the conflict happened. They saw and even experienced many tragic events from 1999 to 2004. By sharing, they are expected to not live in trauma and adversity any longer and try to do more positive things. This activity does not stop at just admitting and dispelling pain, but continues on how to rise to face the future.

A person who is directly involved in a traumatic event or mental shock, such as war, conflict, natural disaster, tragic accident, kidnapping, brutal assault, rape, etc. (Dadang Hawari. 2004: 481-486), can suffer from a disorder called Post-Traumatic Stress Disorder (PTSD). The PTSD symptoms can make those who suffer from it unable to live a normal life. Such condition was first recognized in war veterans. Here, the symptoms include nightmares, fear, and constant worrying which appear within hours or days after the traumatic event. In another case, they may happen within weeks, months, or even years afterward. This is due to the fact that everyone has different nervous system and tolerance to stress.

To heal from Post-Traumatic Stress Disorder is time-consuming and needs gradual process. It will not fade away in a second and the memories of the trauma that has caused it cannot be completely gone. Living with PTSD can be overwhelming, scary, and even crippling. However, people with PTSD can recover, feel safe and calm, and gain self-respect if they take the steps to deal with it and get the right help. There are several ways to do; confiding in parents, family, or friends who are trusted and willing to listen without interrupting, and seeking support from people who have got similar experiences, those who have experienced similar traumatic events and have successfully overcome their trauma in a good way (Dadang Hawari. 2004: 493).

The participants in the Guru Bacarita program generally give testimonies that they have succeeded in expressing what they have felt so far, about the conflict and other religious groups. A participant with initial IR (45 years old) said: "Our parents used to say they were fighting for religion, if they died they would go to heaven. But we all found it difficult to get food and we could not go to school. Is this really a religious command? All lived in hardship and fight and kill each other". IR also gave a testimony that he has discovered new passions after attending the session and is willing to be actively involved in peace building activities.

The communication and meeting among the interfaith teachers in Guru Bacarita is seen as an important point for the dialogue process and peace efforts in Ambon for several reasons: First, the teachers can tell dark stories they have experienced. They can open up about what has caused them to experience trauma. Sharing about what a person has felt and has thought, especially those who have experienced periods of conflict plays a very important role 
in dealing with post-traumatic stress. In doing so, they can get rid of the trauma and start the steps to build a way better future.

Second, an encounter or meeting (bakudapa) with interfaith teachers can get them to know each other and build intimacy. They can sense an awareness of mutual need instead of mutual blame among different communities. The peace initiative that emerges within each teacher's heart is actually the basis for a broader peace effort. Without it, true peace will only be something artificial and temporary.

Third, the Focus Group Discussion (FGD) has led them to get to know each other further and they can be more open to share their stories and common problems. Through this encounter and mutual trust, each person, consciously or not, has expressed a willingness to listen and learn from one another. In turn, the claims of self-defense and self-justification from the two communities that were once in conflict have gradually disappeared.

Fourth, one of the special mechanisms used to defend a group from possible social conflicts is safety valve as an institution to express dissatisfaction with a system or structure. This effort allows a burst of hostility to flow without destroying the entire structure, but helps to "clear the air" in a chaotic situation. The safety valve theory was introduced by Lewis A. Coser. He sees it as a way-out that dispels hostility, without which the relations between the opposing parties would heat up.

Besides conducting the FGD, the Guru Bacarita program also invites the teachers to visit houses of worship. There are four places of worship to visit, Al-Fatah Mosque, Maranatha Church, Swarna Giri Tirta Monastery and Siwa Stana Giri Temple. This visit is attended by all of the Guru Bacarita participants.

The participants generally consider the visit as a new experience. One Muslim participant, for example, said: "I have been here for 30 years, but I have never known about churches, monasteries and temples. I am very happy to have this opportunity”. MU, his initial, also admits that he can get to know other religious groups, make friends with them and show affection for one another through this activity.

Apart from the testimonies delivered by some parties, the visit to places of worship plays a very positive role in building more constructive relationships for the participants with several reasons: First, the teachers are given an opportunity to know the places of worship of other religions by joining this visit. In addition, they also learn about religious diversity as every religion basically teaches love and peace. At the time of the conflict, deep in their hearts they admitted that the relations between religious believers in Ambon were under the concept of mutual love. Here, they reaffirm one another; the mission of all religions is salvation, peace and mutual love among human beings.

Second, their initiative to communicate and meet up (bakudapa) with one another has helped to progressively break the ice and tension caused by the violent conflict. Their communication and meeting plays a significant role in the dialogue process and peace efforts in Ambon. It can gradually prevent suspicion and negative views by each person or group, so that they can act normally, oppose the violence that has occurred and ignore all religious sentiments.

Third, the introduction to religious teachings from different religious groups can offer more insight to the teachings. This is essential to instill and foster tolerance and inclusion among them. Basically, every religious adherent must believe in the eternal truth in their respective teachings. However, they must realize the diverse beliefs have been destined by God, meaning rejecting diversity or plurality is like denying God's gift.

The biggest theological challenge in today's religious life is how a religious person can define himself in the midst of other religions, or in a more technical term commonly used in 
contemporary theology, how he can have a theology in the context of other religions. If we trace the development of theological doctrines, at a glance, religions are exclusive, meaning every religious person believes that salvation only exists in his religion (truth claim). This, in turn, often leads to tensions and conflicts.

At the theological level, confusion must admittedly arise, especially concerning the ways to define oneself in the midst of other religions that also exist and have validity. In fact, some observers believe religions also generally regulate violence and war and even legitimize murder in carrying out their mission. This can be seen, for example, from the confession of Imam Samudra as the perpetrator of the Bali bombing in October 2002. He admitted that he committed the bombing partly because he based his action on the verses in Qur'an (at-Taubah $[9: 5])$ and (at-Taubah [9:29]). ${ }^{2}$

All religions basically guide and lead people to God. Although they perform different rites, all is addressed to One God. In addition, they also have universal values such as recognizing God's existence, upholding justice and equality among humans, paying respect for humanity, building peace among human beings, and maintaining harmonious relations with the natural environment. Every religion also respects the choice of religion from other groups. In fact, the religious teachings of Abraham's descendants (Judaism, Christianity and Islam) have many similarities with religions from the time of Prophet Adam to that of Prophet Muhammad.

According to Nurcholosh Madjid, every religion is essentially an expression of faith in the same God. Like a wheel, the center of the wheel is God, and the spokes are the paths for various religions to connect to the center. This becomes the main point in the perennial philosophy which divides religion into the esoteric and exoteric levels. One religion is different from another at the exoteric level, but is relatively similar at the esoteric level. Therefore, there comes the phrase "One God, Many Paths" (Nurcholish Madjid in Grose B George and Benjamin J, Hubbard (ed), 1999: xix).

Referring to the study of a number of verses in Qur'an, the strong historical relationship and the similarity of the Sharia implemented during the time of Prophet Muhammad with the one before him is evident. The history of religions shows the continuity of revelation. Although Prophet Abraham focused more on the teachings of monotheism, he was the central figure in the semitic environment. The main teachings in Qur'an are in line and in accordance with the ones mentioned in the previous holy books, and the religion brought by Prophet Muhammad is actually a continuation to the religions taught by the prophets before him. Some Islamic teachings such as the prohibition to worship idols, praying, fasting, pilgrimage, circumcision, obligatory baths, the law of stoning, the law of qishash, animals that can and cannot be eaten, usury, drinking alcohol, adultery, and alike, all shows that the Islamic teachings are nothing new (Abd. Moqsith Ghazali. 2009: 121-185).

All religious adherents in the world including Muslims, Christians, Jews, Hindus, Buddhists, Confucians and others, believe in the truth of their respective religions and judge it

\footnotetext{
${ }^{2}$ In his book Aku Melawan Teroris, Solo: Jazera. 2004. Imam Samudra mentions that his action is based on the following verses: 1) And when the sacred months have passed, then kill the polytheists wherever you find them and capture them and besiege them and sit in wait for them at every place of ambush. But if they should repent, establish prayer, and give zakah, let them [go] on their way. Indeed, Allah is Forgiving and Merciful. 2) Fight those who do not believe in Allah or in the Last Day and who do not consider unlawful what Allah and His Messenger have made unlawful and who do not adopt the religion of truth from those who were given the Scripture - [fight] until they give the jizyah willingly while they are humbled.
} 
as an absolute truth. They accept the teachings of their respective religions continuously. If the teachings are historically traced back, it will be found that the source is the God they believe in. During the development, when the God's messengers were no longer in the midst of their people, all the teachings they received from God underwent a change in interpretation and even required new practical instructions, which had not been known when they were alive. This is the answer to why although all religions originally came from God, they have experienced differences over a long period of time. To face such differences, the religious adherents should not impose their opinions on others as the others must maintain what they believe to be absolutely true.

\section{Conclusion}

Many scientists have conducted studies about the conflict and peace in Ambon and the governments and communities have also made efforts to resolve the conflict and build peace. One of the efforts made by the communities is the Guru Bacarita program which is attended by interfaith teachers. It has two major agendas, Focus Group Discussion (FGD) and visits to places of worship.

Practically, this program is a meeting room (bakudapa) for teachers to share stories about their experiences in surviving the social conflicts in 1999-2004 in Maluku, their troubles or suffering due to the loss of their houses, properties, family members, and others. They also share their longing for togetherness that was once created but suddenly vanished due to this turmoil of human tragedy. In addition, they are also introduced to houses of worship from different religions, and the religious teachings which basically uphold peace.

Referring to the testimonies of the participants involved in the program, they admit this program effectively plays a significant role in building stronger relationships among groups of people from different religions. In other words, it contributes to maintaining and building peace in Ambon.

The positive values that claim this Guru Bacarita program worth of developing include: (1) sharing about what a person has felt and has thought, especially those who have experienced periods of conflict plays a very important role in dealing with post-traumatic stress, (2) communication and meeting (bakudapa) with one another has progressively helped break the ice and tension caused by the violent conflict among religious believers, (3) visits to houses of worship and the introduction to religious teachings from different religious groups can offer more insight to the teachings. This is essential to instill and foster tolerance and inclusion among them.

\section{References}

[1] Ala'i Nadjib: Perempuan dan Perdamaian, Catatan tentang Peace Building. Jurnal Tashwirul Afkar. Edisi No

22. (2007).

[2] Al-Qurtuby, Sumanto: Islam dan Kristen, Dinamika Pasca Konflik dan Masa Depan Perdamaian di Ambon.

Jakarta: BPK Gunung Mulia. (1998).

[3] Aritonang, Jan S: Sejarah Perjumpaan Kristen dan Islam di Indonesia, Jakarta : BPK Gunung Mulia. (2004).

[4] Galtung, Johan dan Dietrich Fischer: SpringerBriefs on Pioneers in Science and Practicek . Vol 5. Editor 
Hans Günter Brauch. Springer Heidelberg New York Dordrecht London. (2013).

[5] Gawer, Michelle I: Peace Building: Theoretical and Concrete Perspective”, Jurnal Peace and Change. Vol.

31 No. 4-10 (2016).

[6] George, Grose B dan Benjamin J, Hubbard (ed): Tiga Agama Satu Tuhan, Mizan: Bandung. (1999).

[7] Ghazali, Abd. Moqsith: Argumen Pluralisme Agama, Membangun Toleransi Berbasis Alquran, Depok: Kata

Kita. (2009).

[8] Hawari, Dadang: Al-Quran, Ilmu Kedokteran Jiwa dan Kesehatan Jiwa. Yogyakarta: Dana Bakti Prima

Yasa. Cet XI. (2004).

[9] Kadir, Hatib Abdul: Sape Bale Batu, Batu Bale Dia: Politik Revivalisme Tradisi Siwa Lima Orang Ambon

Pascakonflik. Jurnal Lakon. Vol. 1 No. 1-5 (2012).

[10] Rahawarin, Yunus: Kerjasama antarumat Beragama: Studi Rekonsiliasi Konflik Agama di Maluku dan

Tual. Jurnal Kalam: Jurnal Studi Agama dan Pemikiran IslamVolume 7, Nomor 1-6 (2013).

[11] Samudra, Imam: Aku Melawan Teroris. Solo: Jazera. (2004).

[12] Talakua, Rizard Jemmy: Pasar; Bakudapa Bangun Rekonsiliasi, Refleksi peran perempuan Papalele dalam

Resolusi Konflik. Jurnal KENOSIS, Vol. 3. No. 2-12 (2017). 